\title{
Retraction: Structure based sequence analysis \& epitope prediction of gp41 HIV1 envelope glycoprotein isolated in Pakistan
}

\author{
Syyada Samra Jafri ${ }^{1}$, Saliha Kiran ${ }^{2}$, Syed Babar Jamal ${ }^{3}$ and Masaud Shah ${ }^{1 *}$
}

This article [1] is retracted by the Editor because the peer review process was compromised due to a referee's undeclared conflict of interest. Based on post-publication peer review the Editor cannot trust the veracity of the findings. We apologize to all affected parties.

\begin{abstract}
Author details
'Bioinformatics Research Group, National Center of Excellence in Molecular Biology, University of the Punjab, Lahore, Pakistan. ${ }^{2}$ Government College University, Faisalabad, Pakistan. ${ }^{3}$ International Islamic University Islamabad, Islamabad, Pakistan.
\end{abstract}

Received: 3 October 2012 Accepted: 3 October 2012

Published: 23 October 2012

\section{Reference}

1. Jafri SS, Kiran S, Jamal SB, Shah M: Structure based sequence analysis \& epitope prediction of gp41 HIV1 envelope glycoprotein isolated in Pakistan. Genetic Vaccines and Therapy 2012, 10:4.

*Correspondence: masaudghalib@hotmail.com

${ }^{1}$ Bioinformatics Research Group, National Center of Excellence in Molecular Biology, University of the Punjab, Lahore, Pakistan
Submit your next manuscript to BioMed Central and take full advantage of:

- Convenient online submission

- Thorough peer review

- No space constraints or color figure charges

- Immediate publication on acceptance

- Inclusion in PubMed, CAS, Scopus and Google Scholar

- Research which is freely available for redistribution

Submit your manuscript at www.biomedcentral.com/submit 